\title{
Salt deposits in evaporation ponds: an environmental hazard?
}

\author{
Kenneth K. Tanji $\square$ Colin G. H. Ong $\square$ Randy A. Dahlgren $\square$ Mitchell J. Herbel
}

\begin{abstract}
Only one-fifth of the drainage-impacted lands in the San Joaquin Valley's west side discharge their irrigation return flows into the San Joaquin River. One option for the remaining lands is to dispose of drainage waters in evaporation ponds. Eventually, the evaporite salts that form in these ponds must also be removed. In some cases, these evaporites could constitute hazardous wastes.
\end{abstract}

The water table for about 765,000 acres of the irrigated land in the San Joaquin Valley's west side is less than 5 feet below the land surface (fig. 1). By the year 2000, 918,000 acres are expected to be waterlogged - a condition that can only be alleviated with subsurface drainage systems and re-use or disposal of drainage waters.

In areas of the San Joaquin Valley where natural drainage is limited, growers are using agricultural evaporation ponds to dispose of their saline subsurface drainage waters. Of the 28 evaporation ponds or basins installed between 1972 and 1985 (fig. 2), five are now either inactive or being closed. These ponds occupy about 7,000 acres and vary in size from 10 to 1,800 acres. The evaporation ponds receive about 32,000 acre-feet of subsurface drainage a year from about 56,000 acres of tiledrained croplands.

The drainage waters discharged into these ponds carry with them approximately 800,000 tons of dissolved mineral salts every year, equivalent to about $25 \%$ of the annual salt accumulation in the valley's west side. The annual net weight of salts accumulating in the ponds, when seepage losses are considered, has been estimated at 630,000 tons per year. An additional 2,000 surface acres of ponds may have to be constructed soon for the most severely waterlogged lands.

When the evaporation ponds were constructed, the cumulative impacts on the wildlife they would attract were not known. From 1983 to 1985, the discovery of reduced reproduction, deformities, and death of water birds at the Kesterson National Wildlife Refuge was attributed to the bioaccumulation of selenium (Se) present in the impounded drainage waters from croplands. Today, 13 of the evaporation ponds appear to have the potential to adversely affect bird reproduction. Measures to mitigate the cumulative adverse effects of contaminants in ponds are being investigated.

The drainage waters in these evaporation ponds contain selenium, the only trace element contaminant known to have adverse effects on water birds. Other potentially toxic constituents in drainage waters include boron (B), arsenic (As), molybdenum (Mo), uranium (U), and vanadium (V). As these evaporation ponds mature, evaporite minerals are deposited along the shorelines and pond bottoms, and they will eventually require management.

Some of these evaporites may be classified as hazardous waste. Disposition of the salts accumulating in pond facilities is a long-term concern. This article is an up-
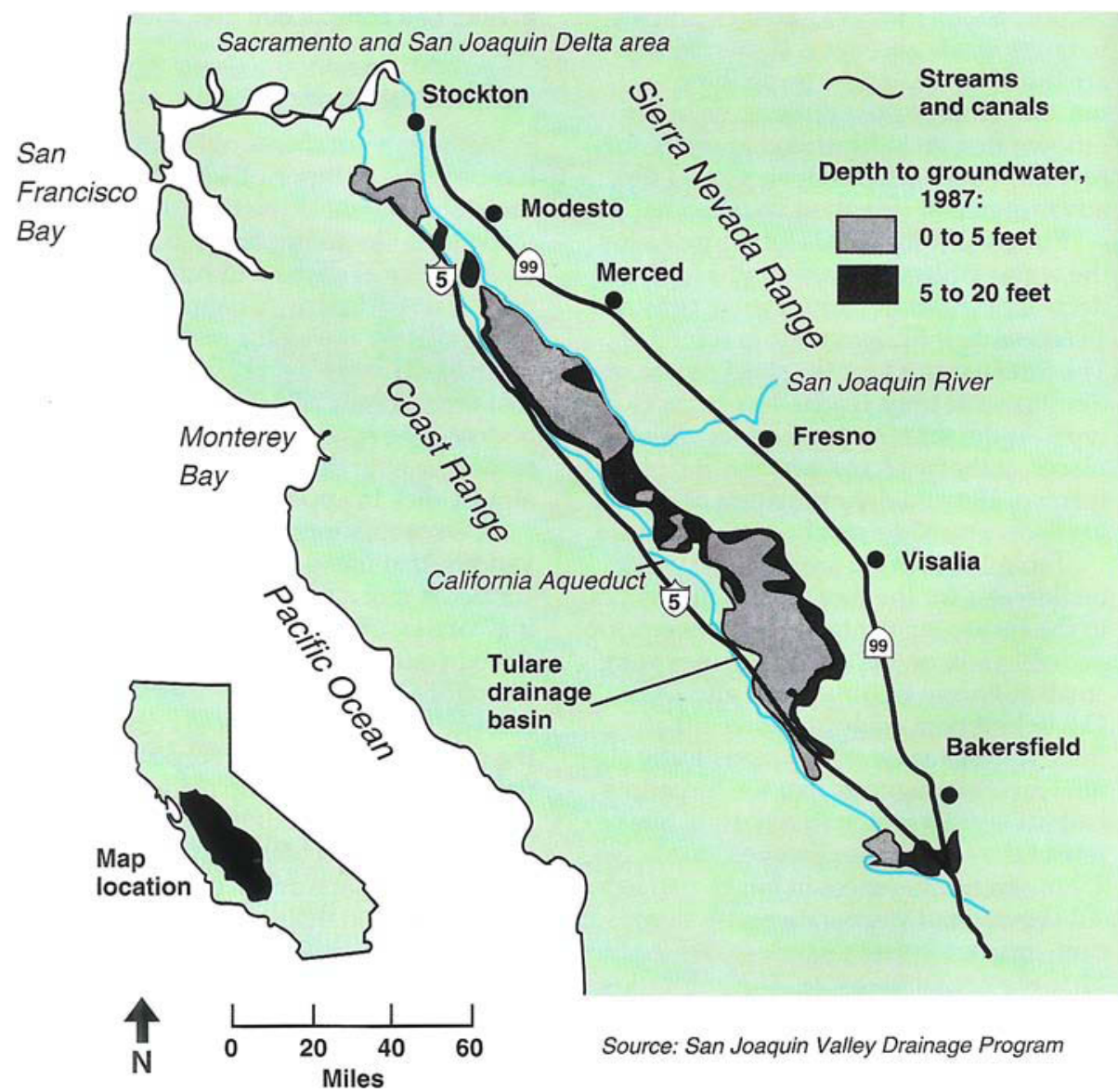

Fig. 1. Shallow water table areas in the San Joaquin Valley. 


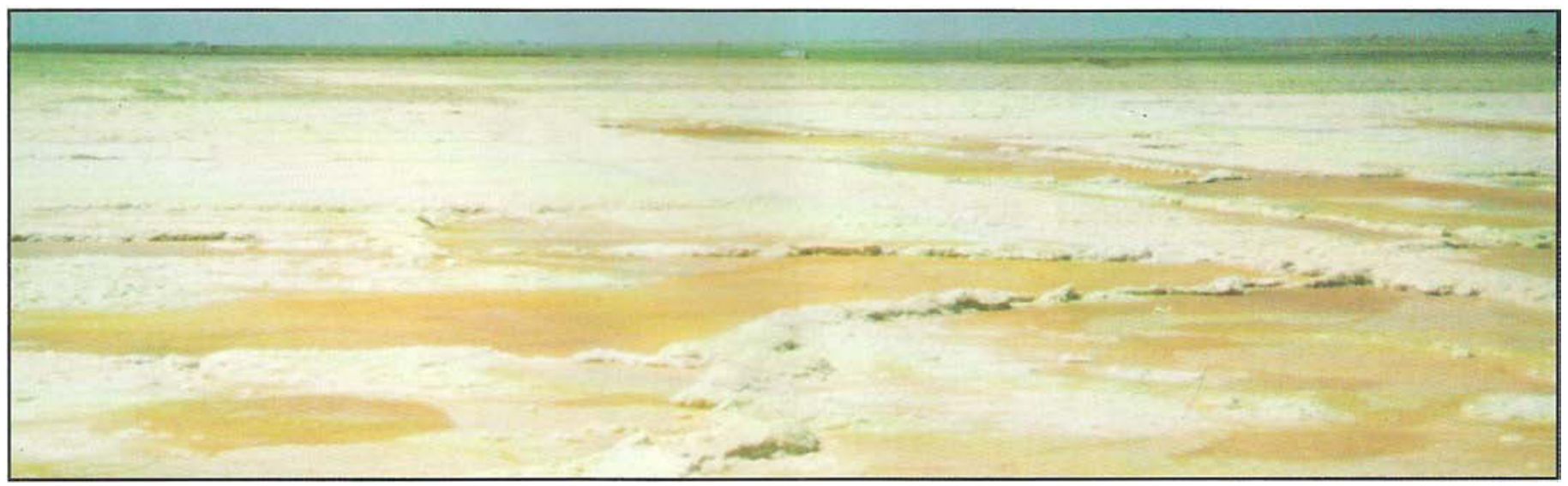

date of an earlier report on evaporation ponds in California Agriculture (SeptemberOctober 1985).

\section{Evaporation ponds and evaporites}

An evaporation pond consists of one or more cells. Typically a cell is a shallow body of water with a large surface area to enhance evaporation. A multiple-cell pond facility consists of several cells, the first of which receives fresh agricultural drainage input. As the pond waters evaporate, the remaining water is passed to the next cell in line, creating a succession of cells with progressively increasing salinities. The final cells have the highest salinity, and are thus conducive to salt formation. In a onecell design, uniform evaporation occurs throughout the cell.

"Evaporites" is the term applied to extremely soluble salt minerals that form in the precipitation stage immediately before total dryness. The most common evaporite minerals found at evaporation ponds include halite $(\mathrm{NaCl})$, thenardite $\left(\mathrm{Na}_{2} \mathrm{SO}_{4}\right)$, and mirabilite $\left(\mathrm{Na}_{2} \mathrm{SO}_{4} \cdot 10 \mathrm{H}_{2} \mathrm{O}\right)$. A more diverse array of evaporites is found along the ponds' shorelines, including gypsum $\left(\mathrm{CaSO}_{4} \cdot 2 \mathrm{H}_{2} \mathrm{O}\right)$, calcite $\left(\mathrm{CaCO}_{3}\right)$, bloedite $\left(\mathrm{Na}_{2} \mathrm{Mg}\left(\mathrm{SO}_{4}\right)_{2} \cdot 4 \mathrm{H}_{2} \mathrm{O}\right)$, burkeite

$\left(\mathrm{Na}_{6} \mathrm{CO}_{3}\left(\mathrm{SO}_{4}\right)_{2}\right)$, and nahcolite $\left(\mathrm{NaHCO}_{3}\right)$. The disposition of this salt load is a longterm concern. There is a potential for commercial salt harvesting, but the presence of selenium, arsenic, boron, mólybdenum, and other potentially toxic elements may constrain use of these salts.

\section{How evaporites form}

Evaporite minerals have widely ranging solubilities. A particular evaporite forms in an evaporation pond when the salt becomes so concentrated that it exceeds its solubility product constant. The pond water must be evapoconcentrated by a factor of 5 to 40 before evaporite minerals begin to form. Temperature changes in solution may affect the solubility of certain salts. Most evaporites become more soluble with higher temperature (e.g., halite and mirabilite), but some do just the opposite (e.g., thenardite and calcite). So-
Pool surface crusts are extremely thin; yet they clearly exhibit the elongated form of mirabilite.

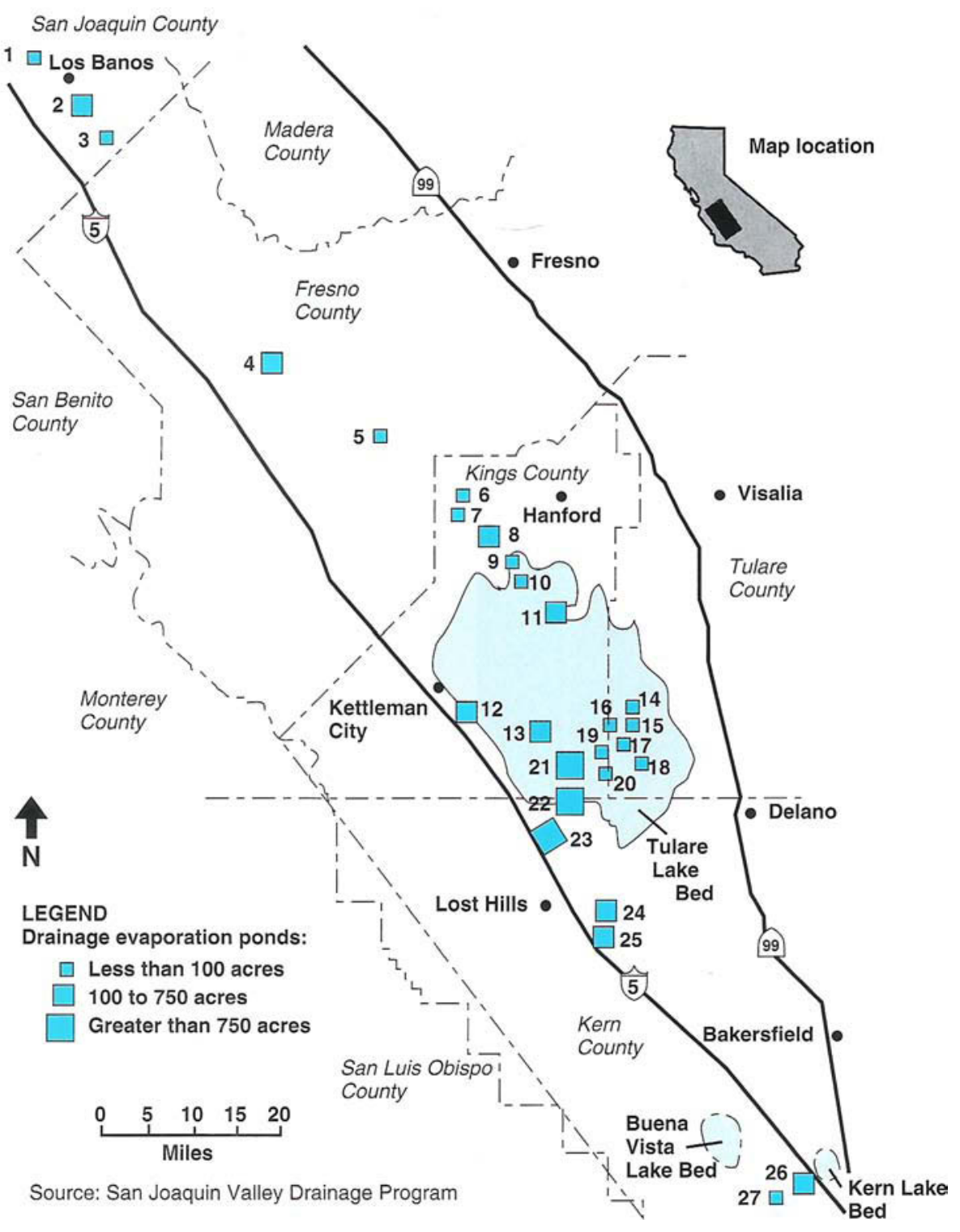

Fig. 2. Location of evaporation ponds in the San Joaquin Valley 


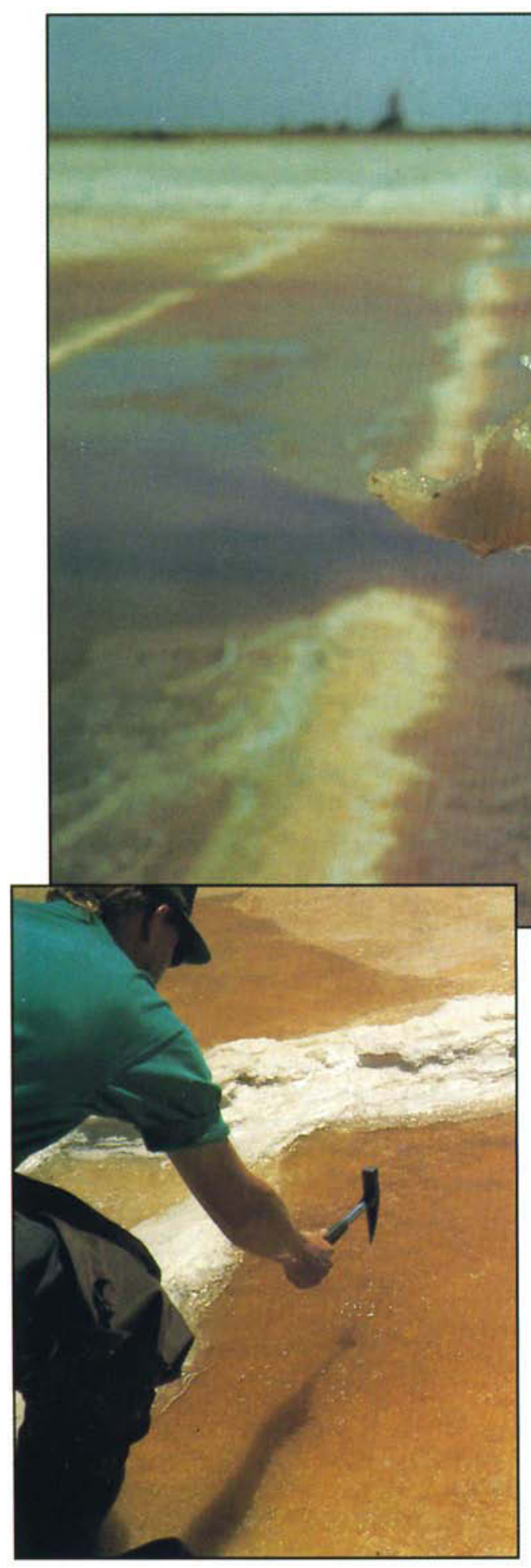

lution temperatures found during field sampling ranged from a low of $43^{\circ} \mathrm{F}\left(6^{\circ} \mathrm{C}\right)$ in February to a high of $106^{\circ} \mathrm{F}\left(41^{\circ} \mathrm{C}\right)$ in August. As an example of the variability of evaporite solubilities, a saturated aqueous solution of $\mathrm{Na}_{2} \mathrm{SO}_{4}$ contains about 9 grams (g) $\mathrm{Na}_{2} \mathrm{SO}_{4}$ per $100 \mathrm{~g} \mathrm{H}_{2} \mathrm{O}$ at $50^{\circ} \mathrm{F}\left(10^{\circ} \mathrm{C}\right)$, and about $49 \mathrm{~g} \mathrm{Na}_{2} \mathrm{SO}_{4} / 100 \mathrm{~g}$ $\mathrm{H}_{2} \mathrm{O}$ at $100^{\circ} \mathrm{F}\left(38^{\circ} \mathrm{C}\right)$.

Evaporites typically need a nucleation site in order to initiate crystal growth. In the ponds, the abundance of suspended particulate matter (clays, phytoplankton,

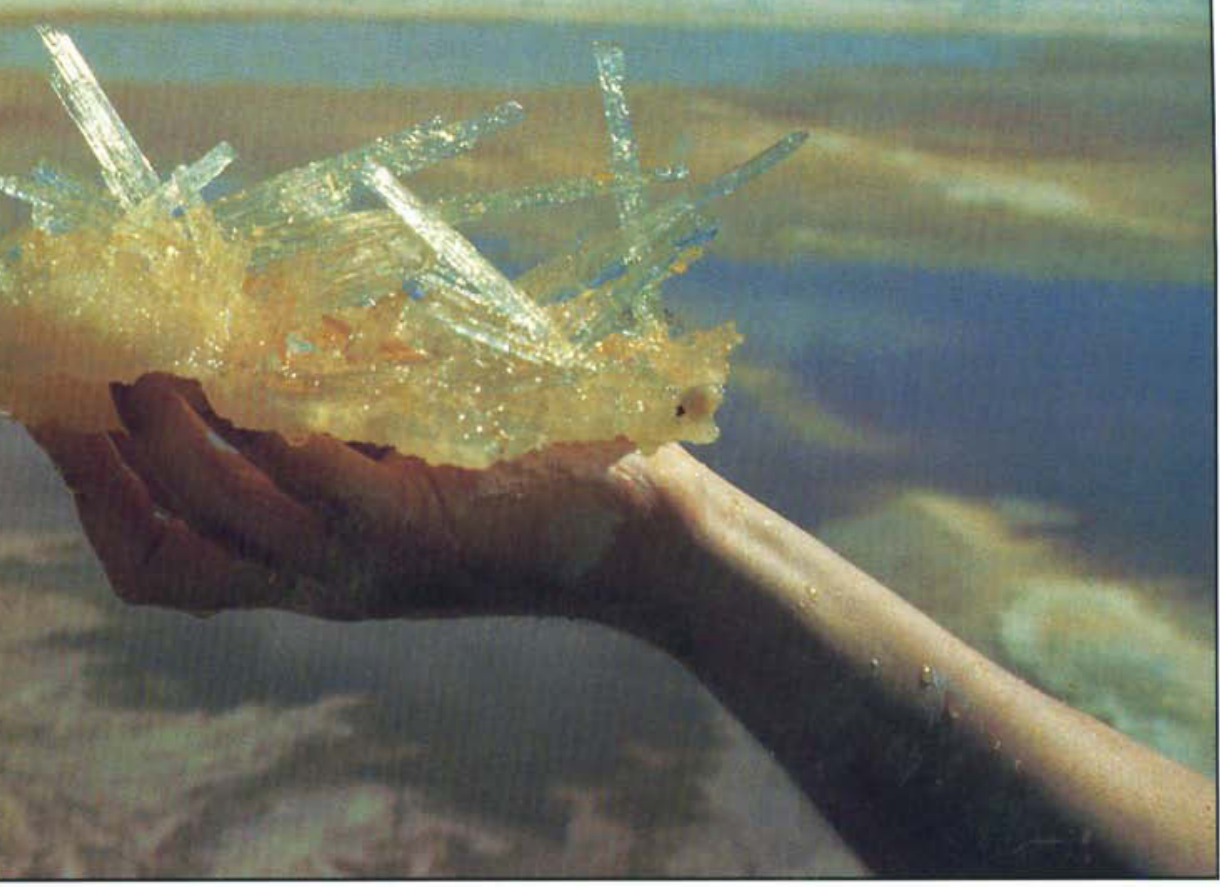

Reduction of agricultural drainage waste water through evaporation in several evaporation ponds in the San Joaquin Valley has led to expansive bed deposits of evaporite minerals. At left, a hypersaline solution pool is sampled for consolidated bottom crust, loose crystals, and pool surface crust. Samples are also taken of the dry material above the waterline.

and decaying detrital material, for example) ensures an ample supply of nucleation sites for crystal growth. Salts also form in the tidal wash area where rapid and repeated wetting and drying favor formation of fine-grained salts. Salts may also form on protruding objects, such as aquatic vegetation and brush that are wetted by water sprays or waves.

\section{Types of evaporite}

The type of evaporite that forms in a pond depends on the initial chemical composition of the pond water and the pathways of evaporative salinization. The principal cation is sodium $(\mathrm{Na})$; the dominant anions are chloride $(\mathrm{Cl})$ and sulfate $\left(\mathrm{SO}_{4}\right)$. Halite (common table salt) forms from the combination of $\mathrm{Na}$ and $\mathrm{Cl}$; the combination of $\mathrm{Na}$ and $\mathrm{SO}_{4}$ forms thenardite or mirabilite, a hydrated form of thenardite. Mirabilite typically forms in pond waters at temperatures less than $90^{\circ} \mathrm{F}\left(32^{\circ} \mathrm{C}\right)$. In contrast, thenardite forms from the dehydration of mirabilite or precipitation in a warmer (more than $90^{\circ} \mathrm{F}\left[>32^{\circ} \mathrm{C}\right]$ ) solution.

Pond waters typically have an electrical conductivity (EC) of between 90 and 100
deciSiemens $(\mathrm{dS} / \mathrm{m})$ when mirabilite or thenardite form. Halite, a more soluble salt, is typically formed in solutions with ECs varying from $165 \mathrm{dS} / \mathrm{m}$ to more than $200 \mathrm{dS} / \mathrm{m}$. The drainage waters initially discharged into ponds have EC values ranging from 7 to $30 \mathrm{dS} / \mathrm{m}$.

Halite crystals are characterized by their cubic shape, or by square faces when a three-dimensional form is obstructed by crystal agglomeration. Well-formed mirabilite tends to be found as translucent, elongated crystals. Thenardite does not have a large crystal form in evaporation ponds; instead, it tends to appear as small, opaque grains when wet, and a fine, white powder when dry.

Field salt samples were analyzed by $X$ ray powder diffraction (XRPD) and by chemical analysis to identify the suite of mineral phases formed from evapoconcentration. The chemical composition was determined by dissolving these highly soluble minerals in a small quantity of distilled-demineralized water and then analyzing the solutions for $\mathrm{Na}, \mathrm{Ca}, \mathrm{Mg}, \mathrm{Cl}$, $\mathrm{NO}_{3}$, and $\mathrm{SO}_{4}$. To determine the degree of mineral hydration, the water content was 
measured by drying a known mass of evaporite sample in an oven.

\section{Pond survey}

The seven salt-producing evaporation ponds sampled in August 1990 were numbers $4,8,9,10,12,14$, and 23 (fig. 2). Halite predominated in ponds 23,12 , and 14 to the south; mirabilite and thenardite were common towards the north in ponds 4,8 , 9 , and 10 . In the cooler month of February 1991, mirabilite predominated; halite was found only at the southernmost pond (number 23); only one cell in a northern pond contained thenardite (pond 4); and three ponds did not have any significant salt deposits for sampling (ponds 5, 8, and 9).

Evaporite contamination. The formation of salts from desiccating pond waters inevitably involves contamination by trace elements that are present in the solution. The concentration and speciation of trace elements in evaporation ponds are altered by several processes and conditions. Redox and $\mathrm{pH}$ conditions dictate the oxidation states of trace elements (e.g., selenate $[\mathrm{SeV}]$, selenite [Se $\left.{ }^{\mathrm{IV}}\right]$, elemental $\mathrm{Se}\left[\mathrm{Se}^{0}\right]$, and selenide [Se-II]). Soluble forms of trace elements may be removed (immobilized) from the pond water column through mineral co-precipitation, adsorption to clays, assimilation by phytoplankton and macrophytes, chemical and microbial reduction, and volatilization of the gaseous form(s). Trace elements also may be mobilized or remobilized into the pond water column through chemical oxidation, desorption from clays, dissolution of evaporites and other minerals, mineralization of organic detrital matter, and excretion from aquatic biota.

A major concern regarding evaporites is the incorporation of potentially toxic trace elements such as selenium, arsenic, boron, or molybdenum, because these elements would essentially be "fixed" in the salt. In examining trace element buildup in the water column, chloride is assumed to be a conservative (nonreactive) constituent of pond waters and an indicator of salinity. During evapoconcentration, boron levels tend to increase in direct proportion to chloride, which indicates that boron also behaves conservatively. In comparison, selenium and molybdenum tend to increase with evapoconcentration (but not in direct proportion to chloride) because of immobilization mechanisms, and unlike boron they do not exhibit elevated concentrations. The fourth trace element, arsenic, is highly reactive. It does not accumulate appreciably in pond water, since it is susceptible to immobilization mechanisms, such as volatilization and reduction.

Boron, selenium, and molybdenum may be present in appreciable quantities during evaporite formation. Trace elements may be adsorbed onto evaporite surfaces, trapped in crystal cavities or between crystal surface planes, or may substitute as a component in the mineral phases. Evaporites also may contain particulate matter (such as clays and organic matter), which may adsorb trace elements. If the ponds are completely dried, all the trace elements that remain in solution may become associated with the evaporites.

Table 1 gives the concentrations of trace elements in the evaporites (solid phase) obtained in the field survey, as well as pond waters (solution phase) collected from the sites where evaporites were obtained. The concentration levels are compared with current hazardous waste criteria for liquids and solids.

The table shows that none of the 55 samples of evaporites contained selenium, arsenic, boron, and molybdenum levels exceeding the hazardous waste criteria for solids. The trace elements determined in the evaporites ranged in value from none detected up to $33 \%$ (for selenium) of the hazardous waste criteria. In contrast, the maximum concentration of these trace elements in the pond waters approached or exceeded the hazardous liquid waste criteria. The selenium concentration in pond 4 (fig. 2), under conditions of near dryness, was eight times greater than the $1 \mathrm{mg} / \mathrm{L}$ hazardous waste criteria. It should be noted that pond 4 has been ordered shut down by the Central Valley Regional Water Quality Control Board, and that remediation studies are underway to dissipate selenium in the evaporation pond through microbial volatilization.

Salt problems in ponds. The removal of salts from ponds is eventually necessary in order to maintain evaporating efficiency. Salts tend to form in large slabs on pond bottoms and also form thin films

\begin{tabular}{|c|c|c|}
\hline Element & $\begin{array}{c}\text { Concentration } \\
\text { range }\end{array}$ & $\begin{array}{l}\text { Waste } \\
\text { criteria* }\end{array}$ \\
\hline $\begin{array}{l}\text { Solid phase } \\
\text { Se } \\
\text { As } \\
\text { B } \\
\text { Mo }\end{array}$ & $\begin{array}{l}\text { ND }+-33 \\
\text { ND-8.6 } \\
\text { ND-980 } \\
\text { ND-94 }\end{array}$ & $\begin{array}{r}100 \\
500 \\
7,000 \\
3,500\end{array}$ \\
\hline $\begin{array}{l}\text { Solution phase } \\
\text { Se } \\
\text { As } \\
\text { B } \\
\text { Mo }\end{array}$ & $\begin{array}{l}0.008-8 \\
N D-12 \\
3-200 \\
1-282\end{array}$ & $\begin{array}{c}1.0 \\
5.0 \\
70 \\
350.0\end{array}$ \\
\hline \multicolumn{3}{|c|}{$\begin{array}{l}{ }^{*} \text { For Se, As, and Mo: Hazardous waste criteria } \\
\text { (threshold limit concentration) for soluble (solution } \\
\text { phase) and total species (solid phase) according to } \\
\text { Title 22, California Administrative Code. For B only: } \\
\text { Designated waste criteria for soluble (solution phase) } \\
\text { and total species (solid phase) according to Title 23, } \\
\text { California Administrative Code. } \\
\text { †ND = none detected }\end{array}$} \\
\hline
\end{tabular}

over the pond water, thereby inhibiting continued and complete water evaporation. In addition, salts have a long-term effect, since the overall salinity of pond water remains high as existing, deposited. salts are dissolved by fresh drainage water inputs.

The problem is that the evaporation rate is inversely proportional to the salinity, and the rate would be far less than that of preceding years. A floating evaporation pan study at pond 4 involving waters of different salinities showed that there could be a decrease of as much as $2 \mathrm{~mm}$ per day in evaporation rate between 14 and $47 \mathrm{dS} /$ $\mathrm{m}$ waters. A pond's optimum capacity for evaporation is based on fresh input and maximum evaporation rate. Failure to remove salts could shorten a pond's lifetime as foreseen in design specifications (typically 15 years). The problem is reduced in multiple-cell pond designs and magnified in one-cell designs.

\section{Management questions}

Forecasting the quantity of dissolved mineral salts discharged into a pond over its designed lifetime is difficult, because of variations in subsurface drainage quantity and quality, and in evaporating efficiency. From early on it was understood that salts would eventually have to be removed, but salt disposal alternatives had not been appraised. The alternatives include salt harvesting for commercial (industrial and agricultural) use and off-site burial or disposal.

Salts containing hazardous levels of toxicants would have to be classified as a toxic waste and would need to be disposed of at Class I waste disposal sites, a costly but necessary option. Our study showed, however, that the evaporites forming in representative evaporation ponds do not contain toxic levels of selenium, arsenic, boron, and molybdenum. The disposal problem, therefore, is eased. Possible commercial use of evaporites is hampered by such economic considerations as the cost of transportation and treatment (purification, for example), as well as market demand for these products.

K. K. Tanji is Professor of Water Science; R. A. Dahlgren is Assistant Professor of Soil Science; and C. G. H. Ong and M. J. Herbel are Research Assistants and Graduate Students in Agricultural and Environmental Chemistry. All are with the Department of Land, Air, and Water Resources, UC Davis.

This research program was supported by the Department of Water Resources (Agreement No. B-56769-1), Water Resources Center of the University of California (UCAL-WRC$W-742$ ), and a Joseph G. Prosser Dissertation Fellowship in Agricultural Water Management to the second author. 